\title{
Production of the secondary metabolites $\gamma$-aminobutyric acid and monacolin K by Monascus
}

Received: 14 May 2002 / Accepted: 11 September 2002

(C) Society for Industrial Microbiology 2003

\begin{abstract}
Aminobutyric acid (GABA), a hypotensive agent, and monacolin $\mathrm{K}$, a cholesterol-lowering drug, can be produced by Monascus spp. Under optimal culture conditions, the products of fermentation using Monascus spp. may serve as a multi-functional dietary supplement and can prevent heart disease. In this study, Monascus purpureus CCRC 31615, the strain with the highest amount of monacolin $\mathrm{K}$, was identified from 16 strains using solid fermentation. Its GABA productivity was particularly high. Addition of sodium nitrate during solidstate fermentation of $M$. purpureus CCRC 31615 improved the productivity of monacolin $\mathrm{K}$ and GABA to $378 \mathrm{mg} / \mathrm{kg}$ and $1,267.6 \mathrm{mg} / \mathrm{kg}$, respectively. GABA productivity increased further to $1,493.6 \mathrm{mg} / \mathrm{kg}$ when dipotassium hydrophosphate was added to the medium.
\end{abstract}

Keywords Monascus sp. $\gamma$-Aminobutyric acid · Monacolin K

\section{Introduction}

Red mold rice has been used as a part of Chinese food for thousands of years and has also been considered an essential part of wine making and other fermented food products. There are many reports on the medical effects of red mold rice both as a folk remedy and in scientific publications [7, 14, 25]. Red mold rice fermented using Monascus spp. is effective in decreasing blood pressure [20], lowering plasma cholesterol levels [3, 4], and has antibacterial activity [24]. $\gamma$-Aminobutyric acid (GABA) has several physiological functions, such as

Y.-C. Su · J.-J. Wang · T.-T. Lin · T.-M. Pan (ه)

Department of Agricultural Chemistry,

National Taiwan University, 1, Sec. 4,

Roosevelt Road, Taipei, Taiwan, ROC

E-mail: tmpan@ccms.ntu.edu.tw

Tel.: + 886-2-23630231 ext 3813; Fax: + 886-2-23627044

J.-J. Wang

Department of Industrial Safety and Hygiene,

Tajen Institute of Technology, Pingdon, ROC neurotransmitting, hypotensive, and diuretic effects $[8$, $21]$. GABA is produced by the decarboxylation of glutamic acid by a glutamate decarboxylase. In the process of making red mold rice, glutamic acid is produced from steamed rice by an acid protease and an acid carboxypeptidase that are secreted upon growth of koji mold [17]. Red mold rice contains a large amount of GABA and possesses anti-hypertensive effects for humans [10]. GABA productivity, which can be measured, is considered to have a major effect in lowering blood pressure.

Monacolin K is a secondary metabolite of Monascus strains. Endo [4] discovered that M. ruber produces an active methylated form of compactin known as monacolin K (lovastatin; mevinolin) in liquid fermentation. Monacolin $\mathrm{K}$ functions as an inhibitor of 3-hydroxy3-methylglutaryl-coenzyme A reductase, which is the regulatory and rate-limiting enzyme of cholesterol biosynthesis [1]. The fact that red mold rice can suppress the synthesis of cholesterol has also been confirmed [16]. High blood cholesterol leads to atherosclerosis and is a causal factor in many types of coronary heart disease, a leading cause of human death. These findings have been widely noted in medical circles [12]. Further research has established that substances with similar molecular structures have the same effect [15].

This study focused on screening the pharmacologically active compounds from a series of Monascus strains with the aim of identifying a strain with maximum productivity of both chemicals.

\section{Materials and methods}

Microorganism and growth conditions

Screening for GABA and monacolin K production was carried out on 16 species and strains of the genus Monascus, purchased from the Culture Collection and Research Center (CCRC) and kept in our laboratory (M. ruber CCRC 31538, M. purpureus CCRC 31497, 31498, 31499, 31501, 31504, 31530, 31540, 31542, 31615, 32966, Monascus sp. CCRC 32807, 32808, 32809 and other M. anka M-13, Monascus sp. S2). The cultures were maintained on potato dextrose agar (PDA) slants at $10^{\circ} \mathrm{C}$, and transferred monthly. 
Chemicals

GABA, monacolin K and citrinin were purchased from Sigma (St. Louis, Mo.). LC grade acetonitride was purchased from Merck (Darmstadt, Germany). Tryptone, yeast extract, peptone, malt extract, PDA broth and Bacto-agar were purchased from Difco (Detroit, Mich.). Reagent grade ethyl acetate was purchased from ALPS (Taiwan).

\section{Seed cultures}

Seed cultures were prepared by transferring a loopful of spores from a PDA agar slant into a $500 \mathrm{ml}$ Hinton flask containing $100 \mathrm{ml}$ basal medium (100 g dextrose, $10 \mathrm{~g}$ peptone, $2 \mathrm{~g} \mathrm{KNO}_{3}, 2 \mathrm{~g}$ $\mathrm{NH}_{4} \mathrm{H}_{2} \mathrm{PO}_{4}, 0.5 \mathrm{~g} \mathrm{MgSO}_{4} \cdot 7 \mathrm{H}_{2} \mathrm{O}, 0.1 \mathrm{~g} \mathrm{CaCl}_{2}$ in $1,000 \mathrm{ml}$ distilled water; $\mathrm{pH}$ adjusted to $6.0[9,19])$. Cultures were incubated at $30^{\circ} \mathrm{C}$ for $48 \mathrm{~h}$ at $110 \mathrm{rpm}$. A $5 \%$ inoculum was then transferred to submerged or solid-state fermentation medium.

Submerged culture for GABA and monacolin K production

Submerged culture GABA production was carried out in $500 \mathrm{ml}$ Hinton flasks containing $100 \mathrm{ml}$ medium $(20 \mathrm{~g}$ rice powder, $40 \mathrm{~g}$ glucose, $10 \mathrm{~g}$ monosodium L-glutamate (MSG), $10 \mathrm{~g}$ peptone in $1,000 \mathrm{ml}$ distilled water; $\mathrm{pH} 5.0$ ) [22]. The flasks were incubated at different temperatures $\left(25^{\circ} \mathrm{C}, 30^{\circ} \mathrm{C}, 37^{\circ} \mathrm{C}\right)$ on a rotary shaker at $110 \mathrm{rpm}$ for 14 days. The GABA concentration was measured at intervals. Submerged culture monacolin K production was carried out in $500 \mathrm{ml}$ Hinton flasks containing $120 \mathrm{ml}$ medium $(60 \mathrm{~g}$ glucose, $25 \mathrm{~g}$ peptone, $5 \mathrm{~g}$ corn steep liquor, $5 \mathrm{~g}$ ammonium chloride in $1,000 \mathrm{ml}$ distilled water) [3]. The flasks were incubated at $30^{\circ} \mathrm{C}$ for 14 days on a rotary shaker at a speed of $110 \mathrm{rpm}$. The monacolin $\mathrm{K}$ concentration was measured at intervals.

Solid-state culture for GABA and monacolin $\mathrm{K}$ production

Long-grain rice was purchased from a local supermarket and was used as the substrate for monacolin $\mathrm{K}$ and GABA production under solid-state cultivation. Except for the parameter under investigation, rice substrate was prepared as follows: $500 \mathrm{~g}$ rice was soaked in distilled water for $8 \mathrm{~h}$. Water was then removed using a sieve. The soaked rice was autoclaved for $20 \mathrm{~min}$ at $121^{\circ} \mathrm{C}$ in a "koji-dish" (the koji-dish is made of wood, dimensions $30 \times 20 \times 5 \mathrm{~cm}$ ). After being cooled, the rice substrate was inoculated with a $5 \%$ spore suspension of a Monascus $\mathrm{sp}$. and the inoculated substrate was cultivated at $30^{\circ} \mathrm{C}$ for 14 days. After cultivation, monacolin K and GABA concentrations were measured [19].

Effect of medium components on GABA

and monacolin $\mathrm{K}$ production

The effect of the nitrogen source (peptone, ammonium sulfate, sodium nitrate, MSG, or yeast extract) and inorganic salts (potassium dihydrogen phosphate, magnesium sulfate, calcium chloride, manganese sulfate) on GABA and monacolin $\mathrm{K}$ production in solid-state culture was analyzed. After the rice was sterilized and cooled, various nitrogen sources $(1 \%)$ and inorganic salts $(0.1 \%)$ were added individually to determine their effect on GABA and monacolin $\mathrm{K}$ production.

\section{Determination of the monacolin $\mathrm{K}$ concentration}

Methods for determination of the monacolin $\mathrm{K}$ concentration under different conditions were according to Wang et al. [23].

\section{Submerged culture}

Fermented broth $(5 \mathrm{ml})$ from the flasks was homogenized and adjusted to $\mathrm{pH} 3.0$ with $2 \mathrm{~N} \mathrm{H}_{3} \mathrm{PO}_{4}$ and then extracted with $5 \mathrm{ml}$ ethyl acetate. The extract was centrifuged at 3,000 $\mathrm{g}$ for $8 \mathrm{~min}$. The supernatant $(1 \mathrm{ml})$ was mixed with trifluoroacetic acid $(10 \mathrm{ml}, 1 \%)$ for lactonization of the monacolin $\mathrm{K}$. The resulting mixture was then concentrated to dryness under reduced pressure. The residue was resuspended in $1 \mathrm{ml}$ acetonitrile for HPLC analysis.

Solid-state culture

Mature red mold rice $(1 \mathrm{~g})$ was suspended in $5 \mathrm{ml}$ ethyl acetate at $70^{\circ} \mathrm{C}$ for $1.5 \mathrm{~h}$. The suspension was then filtered through filter paper. The filtrate was evaporated under vacuum. After lactonization, the resulting mixture was added to $1 \mathrm{ml}$ acetonitrile and subjected to preparatory HPLC analysis.

\section{Chromatographic conditions}

Chromatographic separation was achieved on a Beckman Ultrasphere ODS column $(150 \times 4.6 \mathrm{~mm}$ ID). Acetonitrile:water $(72: 28, \mathrm{v} / \mathrm{v})$ was used as the mobile phase. The eluent was pumped at a flow-rate of $0.5 \mathrm{ml} / \mathrm{min}$. The UV detector was at $238 \mathrm{~nm}$.

\section{Determination of the GABA concentration}

GABA concentrations were determined as in [11]. Mature red mold rice $(5 \mathrm{~g})$ was soaked in $40 \mathrm{ml} 60 \%$ ethanol solution at $25^{\circ} \mathrm{C}$ for $24 \mathrm{~h}$. After filtration $(0.45 \mu \mathrm{m})$, the filtrate was analyzed using a Beckman 6300 amino acid analyzer (column: spherical cation-exchange resin $10 \mathrm{~cm}$, Lithium column PN 338051)

Qualitative analysis of citrinin using thin-layer chromatography

Thin layer chromatography (TLC) of citrinin was performed according to [2]. Red mold rice was extracted with acetonitrile. The filtered extract was twice defatted using isooctane. After adding an equal amount of water and acidifying to $\mathrm{pH} 4.5$ with $\mathrm{H}_{2} \mathrm{SO}_{4}(50: 50$, $\mathrm{v} / \mathrm{v}$ ), the extract was partitioned with $\mathrm{CHCl}_{3}$. The lower phase was evaporated to dryness, and then dissolved in methanol before analyzing by TLC. TLC was performed on $10 \times 20 \mathrm{~cm}$ aluminum sheets pre-coated with silica gel 60 . Prior to analysis, the plates were impregnated with oxalic acid (10\% in methanol). Citrinin and samples were spotted on silica gel plates. Chloroform-acetone $(90: 10, v / v)$ followed by toluene-ethyl acetate-formic acid (60:30:10, $\mathrm{v} / \mathrm{v} / \mathrm{v}$ ) were used to conduct two-dimensional analysis.

\section{Results}

\section{Screening of strains}

By using submerged culture or solid culture on the sixteen strains it was possible to examine initially the productivity of GABA and monacolin K (Figs. 1, 2). More GABA was produced in solid culture than in submerged culture (Fig. 1), with a maximum production of $1,031.13 \mathrm{mg} / \mathrm{kg}$ (M. purpureus CCRC 31540). Figure 2 shows that, except for strains of $M$. purpureus CCRC 31499, M. purpureus CCRC 31615 , and $M$. anka M-13, the productivity of monacolin $\mathrm{K}$ was not very high $(<100 \mathrm{mg} / \mathrm{kg})$ for the remaining 13 strains, regardless of whether they were cultivated in solid state or submerged culture. The highest productivity of monacolin $\mathrm{K}$ in the 16 strains was $M$. purpureus CCRC 31615 strain, with a yield of $237 \mathrm{mg} / \mathrm{kg}$.

Monacolin K productivity was not as high as that of GABA when these 16 Monascus strains were used (Figs. 1, 2). GABA was produced in both solid state and 


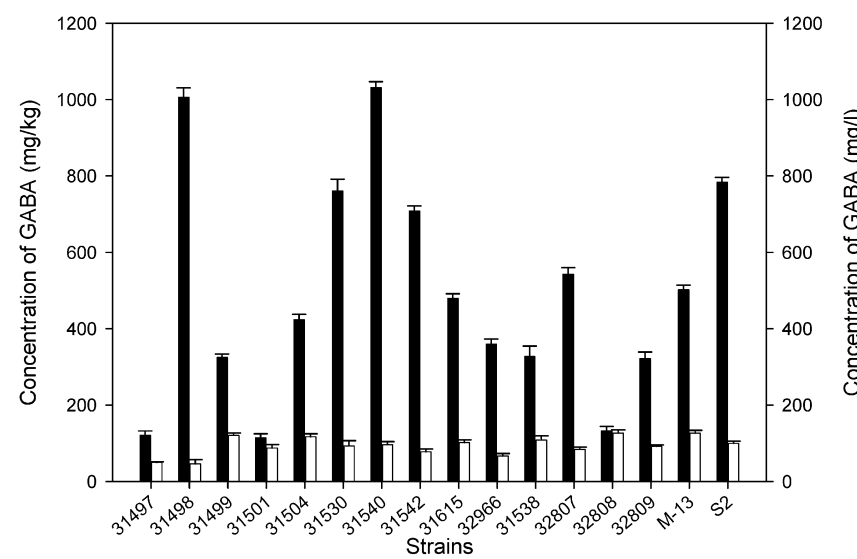

Fig. $1 \gamma$-Aminobutyric acid (GABA) concentration in solid (closed squares) and submerged (open squares) cultures. The values represent the mean $\pm \mathrm{SD}(n=3)$

submerged cultures. However, different strains resulted in varying monacolin $\mathrm{K}$ productivity (Fig. 2). Solid state cultivation always produced more monacolin $\mathrm{K}$ and GABA than submerged cultivation, perhaps because monacolin $\mathrm{K}$ and GABA were more stable and were easily released from rice grains under conditions of solid state cultivation, while submerged cultivation resulted in accumulation of both monacolin $\mathrm{K}$ and GABA on the mycelium. The yield of Monascus pigment from solid cultivation was higher than submerged cultivation as pointed out by Johns and Stuart [6]. Although both Monascus pigment and monacolin $\mathrm{K}$ are polyketides, it has yet to be determined whether monacolin $\mathrm{K}$ will have the same effect as Monascus pigment.

Since $M$. purpureus CCRC 31615 produced the highest amount of monacolin $\mathrm{K}$ and a significant amount of GABA, M. purpureus CCRC 31615 was selected as the target strain for further study. Furthermore, M. purpureus CCRC 31615 accumulated ten amino acids in solid-state cultures (Table 1). The relative amounts of amino acids produced were in the order: Ala, Glu, GABA, Gln, Asp, Ser, Cys, Aln, Orn, Lys.

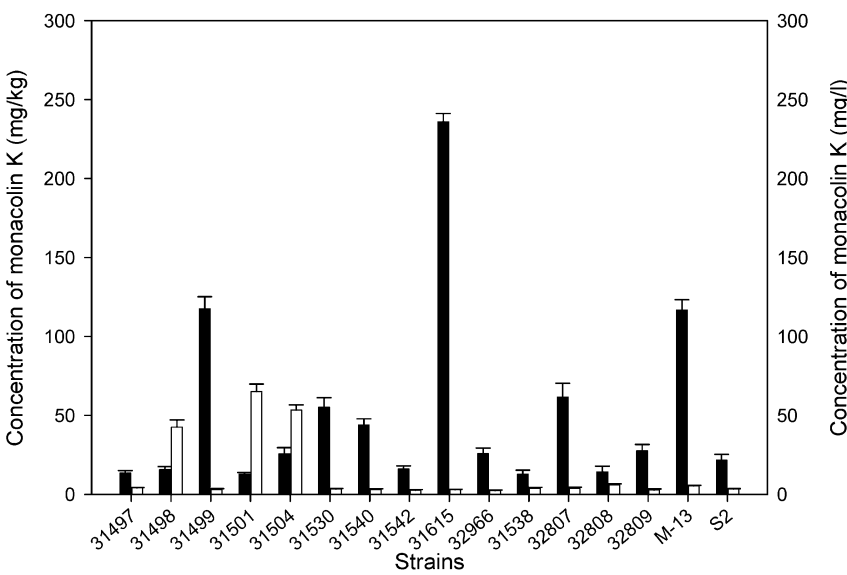

Fig. 2 Monacolin $\mathrm{K}$ concentration in solid (closed squares) and submerged (open squares) cultures. The values represent the mean $\pm \mathrm{SD}(n=3)$
The solid state medium used in this study was rice. Rice contains sufficient carbon sources, therefore further optimization efforts focused on various nitrogen sources and inorganic salts.

Effect of inoculum size on the productivity of GABA and monacolin $\mathrm{K}$

Inocula $(20,25$, and $30 \mathrm{ml})$ were administered to the prepared rice $(500 \mathrm{~g})$. After 10 days at $30^{\circ} \mathrm{C}$, the productivity of GABA and monacolin $\mathrm{K}$ were measured and are shown in Fig. 3. Inoculum size had little effect

Table 1 Production of amino acids by Monascus purpureus CCRC 31615. GABA $\gamma$-Aminobutyric acid

\begin{tabular}{lcc}
\hline Amino acid & Composition $(\%)$ & Production $(\mu \mathrm{mol} / \mathrm{g})$ \\
\hline Asp & 6.81 & 4.45 \\
Ser & 5.00 & 2.31 \\
Glu & 15.50 & 10.53 \\
Gln & 13.01 & 11.03 \\
Aln & 3.59 & 1.29 \\
Ala & 16.12 & 7.57 \\
Cys & 3.93 & 2.26 \\
GABA & 14.36 & 4.70 \\
Orn & 3.53 & 1.23 \\
Lys & 2.45 & 1.13 \\
Other & 15.70 & - \\
\hline
\end{tabular}

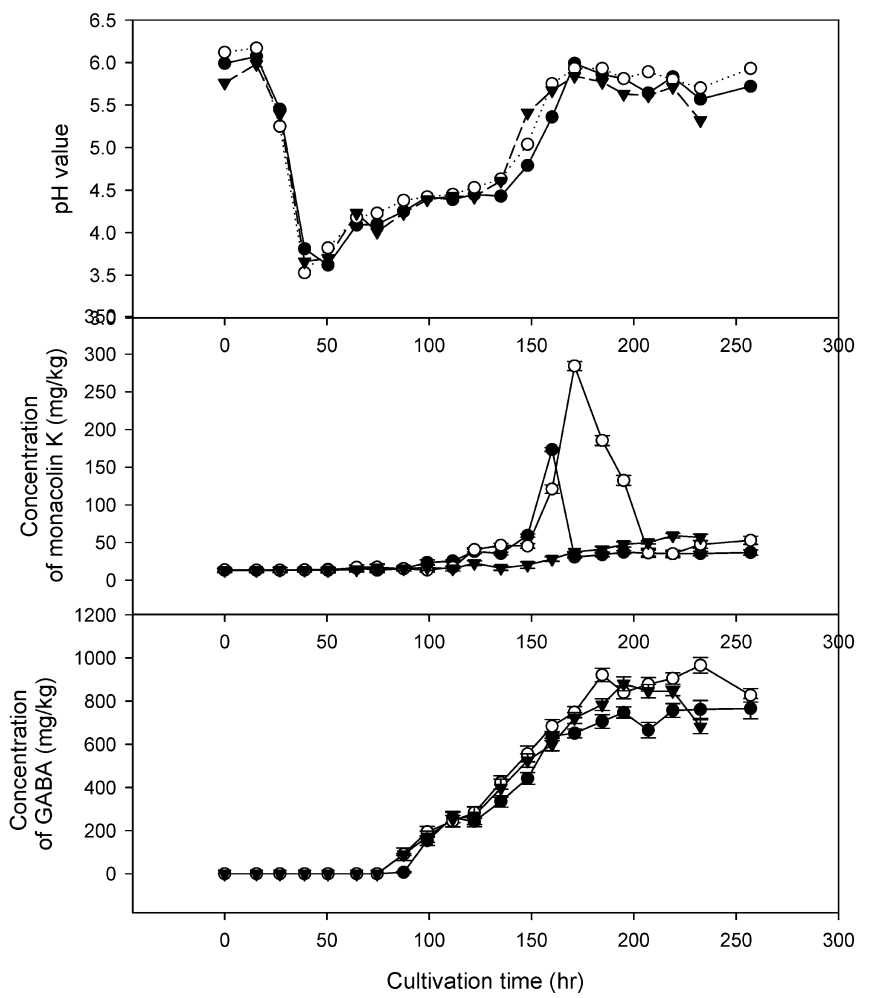

Fig. 3 Effect of inoculum size on the production of GABA and monacolin K by Monascus purpureus CCRC 31615. Medium: rice, culture conditions: $30^{\circ} \mathrm{C}$, inoculum size: $20 \mathrm{ml}$ (closed circles); $25 \mathrm{ml}$ (open circles); $30 \mathrm{ml}$ (closed triangles). The values represent the mean $\pm \mathrm{SD}(n=3)$ 
on GABA productivity. When a $25 \mathrm{ml}(5 \%)$ inoculum was used, the yield of GABA reached $965.71 \mathrm{mg} / \mathrm{kg}$. In contrast, inoculum size had a significant effect on the productivity of monacolin $\mathrm{K}$. Inoculation with $25 \mathrm{ml}$ resulted in a significant increase in monacolin $\mathrm{K}$ productivity with more than $280 \mathrm{mg} / \mathrm{kg}$ produced.

Effect of temperature on GABA and monacolin $\mathrm{K}$ productivity

Because $M$. purpureus CCRC 31615 performed poorly at $25^{\circ} \mathrm{C}$ (Fig. 4), GABA production was low at that temperature. However, when the temperature reached $30^{\circ} \mathrm{C}$, the yield of GABA jumped to $961.35 \mathrm{mg} / \mathrm{kg}$. In contrast, at $37^{\circ} \mathrm{C}$ for $150 \mathrm{~h}$, the yield of GABA decreased, perhaps because GABA decomposed quickly above $30^{\circ} \mathrm{C}$. Furthermore, a higher yield of monacolin $\mathrm{K}$ was achieved at $30^{\circ} \mathrm{C}$ (Fig. 4). Consequently, $30^{\circ} \mathrm{C}$ is the optimal temperature for $M$. purpureus CCRC 31615 strain to produce GABA or monacolin $\mathrm{K}$.

Effect of nitrogen source on GABA and monacolin $\mathrm{K}$ productivity

The effects on GABA and monacolin K productivity of adding various nitrogen sources (to $1 \%$ ) are shown in

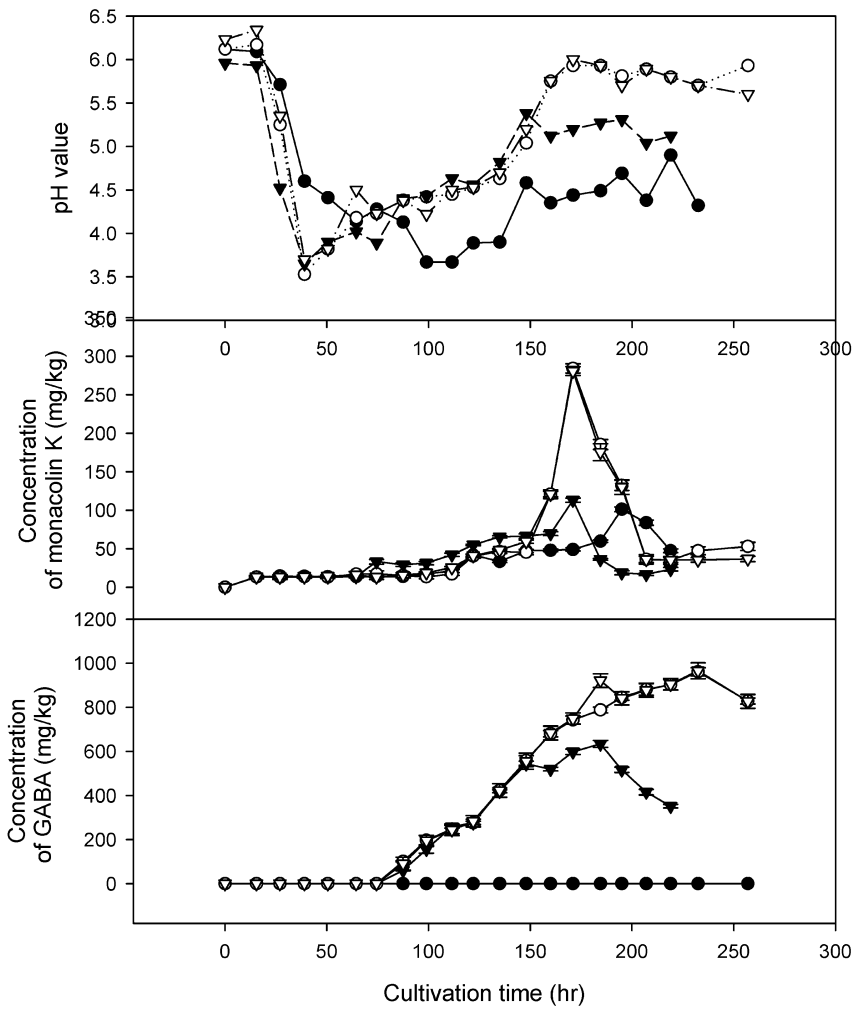

Fig. 4 Effect of temperature on the production of GABA and monacolin $\mathrm{K}$ by $M$. purpureus CCRC 31615 Medium: rice, inoculum size: $25 \mathrm{ml} / 500 \mathrm{~g}, 25^{\circ} \mathrm{C}$ (closed circles); $30^{\circ} \mathrm{C}$ (open circles); $37^{\circ} \mathrm{C}$ (closed triangles); control (open triangles). The values represent the mean $\pm \mathrm{SD}(n=3)$
Fig. 5. Ammonium sulfate did not contribute to GABA production. Rather, the $\mathrm{pH}$ value was lower than 3.0 throughout the entire process, and only yellow and orange pigments were produced.

Other nitrogen sources, like peptone, sodium nitrate, MSG, and yeast extract, contributed to the production of GABA, which reached about $1,000 \mathrm{mg} / \mathrm{kg}$ with a yield of $1,267.6 \mathrm{mg} / \mathrm{kg}$ when sodium nitrate was added. On the other hand, adding MSG reduced the yield of monacolin $\mathrm{K}$ to zero, whereas adding ammonium sulfate had no effect on monacolin $\mathrm{K}$ yield. Sodium nitrate was the optimum nitrogen source for M. purpureus CCRC 31615 as it resulted in the highest productivity for both monacolin $\mathrm{K}$ and GABA.

Effect of inorganic salts on GABA and monacolin K productivity

The addition of $0.1 \%$ of various inorganic salts to the basic medium positively affected GABA and monacolin K productivity (Fig. 6).

To produce GABA only, the addition of the inorganic salts $\mathrm{K}_{2} \mathrm{HPO}_{4}, \mathrm{CaCl}_{2} \cdot 2 \mathrm{H}_{2} \mathrm{O}$ and $\mathrm{MnSO}_{4} \cdot 4 \mathrm{H}_{2} \mathrm{O}$ could be helpful. When $\mathrm{NaNO}_{3}$ and $\mathrm{MnSO}_{4} \cdot 4 \mathrm{H}_{2} \mathrm{O}$ were

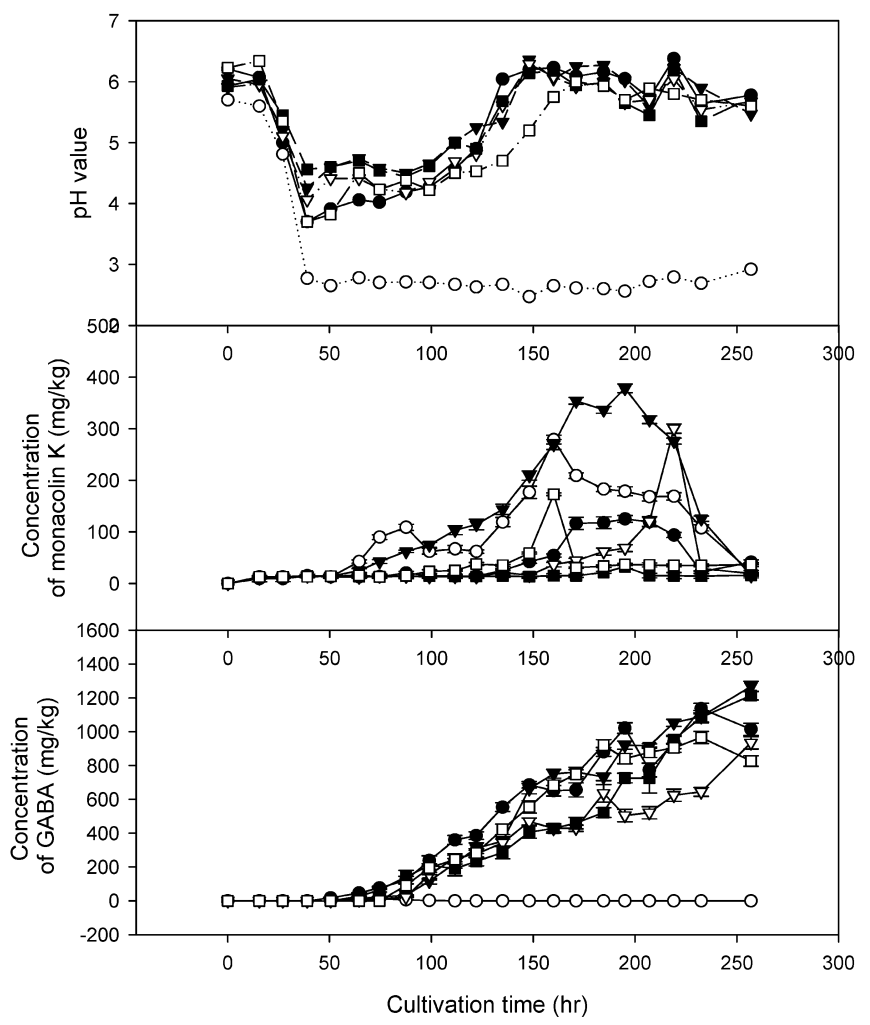

Fig. 5 Effect of various nitrogen sources on the production of GABA and monacolin K by M. purpureus CCRC 31615 Medium: rice, culture conditions: $30^{\circ} \mathrm{C}$, nitrogen source concentration: $1 \%$ peptone (closed circles); $\left(\mathrm{NH}_{4}\right)_{2} \mathrm{SO}_{4}$ (open circles); $\mathrm{NaNO}_{3}$ (closed triangles); yeast extract (open triangles); monosodium L-glutamate (MSG) (closed squares); control (open squares). The values represent the mean $\pm \operatorname{SD}(n=3)$ 


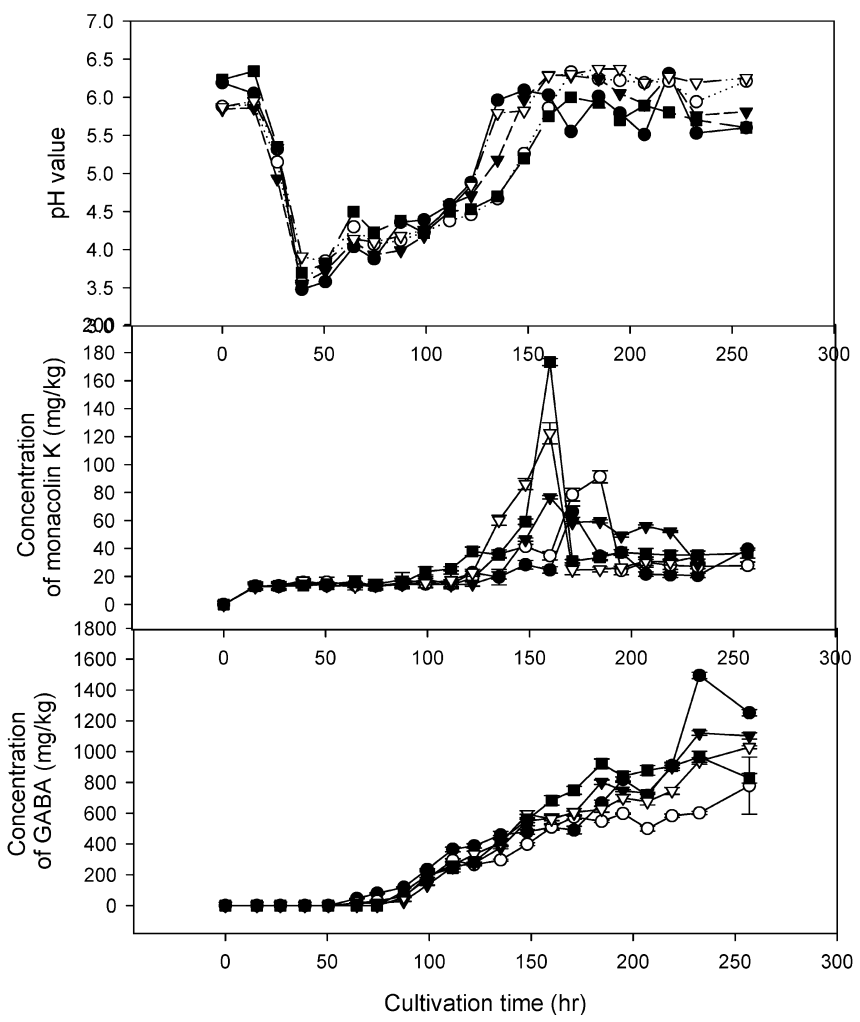

Fig. 6 Effect of inorganic salts on the production of GABA and monacolin $\mathrm{K}$ by $M$. purpureus CCRC 31615 . Medium: rice, culture conditions: $30^{\circ} \mathrm{C}$, mineral concentration: $0.1 \% \mathrm{KH}_{2} \mathrm{PO}_{4}$ (closed circles); $\mathrm{MgSO}_{4} \cdot 7 \mathrm{H}_{2} \mathrm{O}$ (open circles); $\mathrm{CaCl}_{2} \cdot 7 \mathrm{H}_{2} \mathrm{O}$ (closed triangles); $\mathrm{MnSO}_{4} \cdot 4 \mathrm{H}_{2} \mathrm{O}$ (open triangles; control (closed squares). The values represent the mean $\pm \mathrm{SD}(n=3)$

both added to the basic medium (Fig. 7), GABA productivity reached $1,396.04 \mathrm{mg} / \mathrm{kg}$, while monacolin $\mathrm{K}$ productivity was still very low.

Detection of citrinin during solid and submerged culture

TLC analysis showed that no citrinin was detected in either solid or submerged culture (data not shown).

\section{Discussion}

Analysis of the 16 strains in submerged culture and solid culture for both GABA and monacolin $\mathrm{K}$ productivity resulted in the choice of solid culture over submerged culture. M. purpureus CCRC 31615 was selected as the best strain for further study because it produced the highest amount of both GABA and monacolin $\mathrm{K}$ in solid culture. GABA production reached $1,396.04 \mathrm{mg} / \mathrm{kg}$ and monacolin $\mathrm{K}$ production reached $26.77 \mathrm{mg} / \mathrm{kg}$ when the basic medium was supplemented with both $\mathrm{NaNO}_{3}$ and $\mathrm{MnSO}_{4} \cdot 4 \mathrm{H}_{2} \mathrm{O}$.

Citrinin, a nephrotoxic agent, is produced by $M$. purpureus or $M$. ruber in both submerged and solidstate cultures. According to Blanc et al. [2, 5], there is

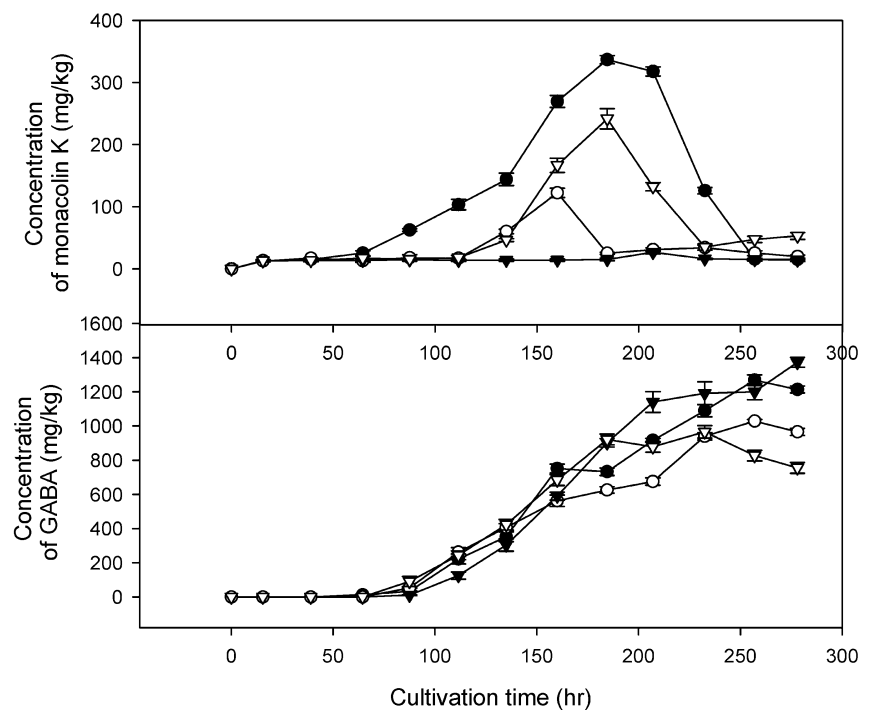

Fig. 7 Effect of addition of $\mathrm{NaNO}_{3}$ and $\mathrm{MnSO}_{4} \cdot 4 \mathrm{H}_{2} \mathrm{O}$ on the production of GABA and monacolin $\mathrm{K}$ by $M$. purpureus $\mathrm{CCRC}$ 31615. Medium: rice, culture conditions: $30^{\circ} \mathrm{C}, 1 \% \mathrm{NaNO}_{3}$ (closed circles); $0.1 \% \quad \mathrm{MnSO}_{4} \cdot 4 \mathrm{H}_{2} \mathrm{O}$ (open circles); $1 \% \mathrm{NaNO}_{3}+0.1 \%$ $\mathrm{MnSO}_{4} \cdot 4 \mathrm{H}_{2} \mathrm{O}$ (closed triangles); control (open triangles). The values represent the mean $\pm \mathrm{SD}(n=3)$

some risk of citrinin contamination in the fermentation process. However, it could be avoided either by detoxification of the red mold rice, use of a species that does not produce citrinin or by adjusting the fermentation conditions for citrinin-free production. Nevertheless, no citrinin was detected in this study, perhaps because the citrinin concentration was below the level of detection by TLC. Further analysis using HPLC with UV/fluorescence detection or enzyme immunoassays would clarify the existence of citrinin [18].

In this study, a maximum amount of $378 \mathrm{mg} / \mathrm{kg}$ of monacolin $\mathrm{K}$ was produced. Although this is less than reported in other studies [13], this study employed a different approach in that $M$. purpureus combined with solid state cultivation to seek optimum conditions for producing maximum amounts of both monacolin $\mathrm{K}$ and GABA. Although the proposed method did not yield maximum productivity of monacolin $\mathrm{K}$, it resulted in a significant amount of GABA. Furthermore, the purpose of this study was to provide a means to produce food products by direct fermentation on a nutraceutical containing both active ingredients rather than the production of the individual medicinal components. In short, this study lays an emphasis on a dietary product that could be directly consumed.

\section{References}

1. Albert AW (1988) Discovery, biochemistry and biology of lovastatin. Am J Cardiol 62:10J-15J

2. Blanc PJ, Laussac JP, Le Bars J, Le Bars P, Loret MO, Pareilleux A, Prome D, Prome JC, Santerre AL, Goma G (1995) Characterization of monascidin A Monascus as citrinin. Int J Food Microbiol 27:201-213 
3. Endo A (1979) Monacolin K, a new hypocholesterolemic agent produced by Monascus species. J Antibiot 32:852-854

4. Endo A (1985) Compaction (ML-236B) and related compounds as potential cholesterol-lowering agents that inhibit HMG-CoA reductase. J Med Chem 28:401-405

5. Hajjaj H, Blanc PJ, Groussac E, Goma G, Uribelarrea JL, Loubiere P (1999) Improvement of red pigment/ citrinin production ratio as a function of environment conditions by Monascus ruber. Biotechnol Bioeng 64:497-501

6. Johns MR, Stuart DM (1991) Production of pigments by Monascus purpureus in solid culture. J Ind Microbiol 8:23-28

7. Juzlova P, Martinkova L, Kren V (1996) Secondary metabolites of the fungus Monascus: a review. J Ind Microbiol Biotechnol 16:163-170

8. Keisuke T, Tomio I, Nobukazu T, Hiroshi O, Shirou A, Shouichi T, Yasue N (1992) Extraction of hypotensive substance from wheat beni-koji. Nippon Shokuhin Kogyo Gakkaishi 39:913-918

9. Kiyohara $\mathrm{H}$, Watanabe $\mathrm{T}$, Imai J, Takizawa $\mathrm{N}$, Hatta $\mathrm{T}$, Nagao K, Yamaoto A (1990) Intrageneric hybridization between Monascus anka and Aspergillus oryzae by protoplast fusion. Appl Microbiol Biotechnol 33:671-676

10. Kohama Y, Matsumoto S, Mimura T, Tanabe N, Inada A, Nakanishi T (1987) Isolation and identification of hypotensive principles in red-mold rice. Chem Pharm Bull 35:24842489

11. Kono I, Himeno K (2000) Changes in $\gamma$-aminobutyric acid content during beni-koji making. Biosci Biotechnol Biochem 64:617-619

12. Lin CF (1992) New application of Monascus species to health food. J Food Ind 24:41-45

13. Liu QX (1995) Study on the production of cholesterol lowering agent lovastatin by Aspergillus terreus ATCC 20542. Masters Thesis, Graduate Institute of Agricultural Chemistry, National Taiwan University

14. Ma J, Li Y, Ye Q, Li J, Hua Y, Ju D, Zhang D, Copper R, Chang M (2000) Constituents of red yeast rice, a traditional
Chinese food and medicine. J Agric Food Chem 48:5220 5225

15. Manzoni M, Bergomi S, Rollini M, Cavazzoni V (1999) Production of statins by filamentous fungi. Biotechnol Lett 21: 253-257

16. Martinkova L, Juzlova P, Vesely D (1995) Biological activity of polyketide pigments produced by the fungus Monascus. J Appl Bacteriol 79:609-616

17. Narahara H (1994) Koji-mold and its product koji. J Brew Soc Jpn 89:873-881

18. Reinhar H, Zimmerli B (1999) Reversed-phase liquid chromatographic behavior of the mycotoxins citrinin and ochratoxin A. J Chromatogr A 862:147-159

19. Su YC, Chen WL, Fang HY, Wong HC, Wang WH (1970) Mycological study of Monascus anka. J Chin Agric Chem Soc 8:46-54

20. Tsuji K, Ichikawa T, Tanabe N, Abe S, Tarui S, Nakagawa Y (1992) Effect of two kinds of koji on blood pressure in spontaneously hypertensive rats. Nippon Nogeikagaku Kaishi 66:1241-1246

21. Ueno Y, Hayakawa K, Takahashi S, Oda K (1997) Purification and characterization of glutamate decarboxylase from Lactobacillus brevis IFO 12005. Biosci Biotechnol Biochem 61: $1168-1171$

22. Wang CL (1998) Studies on the glutamate decarboxylase from Monascus purpureus. Masters Thesis, Graduate Institute of Agricultural Chemistry, National Taiwan University

23. Wang UL, Houng JY, Chang HS, Chien HCR, Hsu WH (1998) Selection of drug-resistant mutants of Monascus pilosus for enhanced monacolin K production. J Chin Agric Chem Soc $36: 192-200$

24. Wong HC, Bau YS (1977) Pigmentation and antibacterial activity of fast neutron- and X-ray-induced strains of Monascus purpureus Went. Plant Physiol 60:578-581

25. Wong HC, Koehler PE (1981) Production and isolation of an antibiotic from Monascus purpureus and its relationship to pigment production. J Food Sci 46:589-592 